K.V. Voitko, O.M. Bakalinska, M.T. Kartel

\title{
CATALYTIC DECOMPOSITION OF ORGANIC PEROXIDES IN NON-AQUEOUS MEDIA UNDER METAL-FREE NANOPOROUS AND NANOSIZED CARBOCATALYSTS
}

\author{
Chuiko Institute of Surface Chemistry of National Academy of Sciences of Ukraine \\ 17 General Naumov Str., Kyiv, 03164, Ukraine, E-mail: kvoitko@gmail.com
}

\begin{abstract}
The aim of this study is to investigate the catalytic system "Carbon nanomaterial-diacyl peroxide molecule-nonaqueous medium" and determine main factors that influence on carbon catalyst's effectiveness. The catalytic activity of nanoporous (activated carbon (AC)) and nanosized (multiwalled carbon nanotubes (CNT)) carbon catalysts and their modified forms were investigated in the decomposition of benzoyl and lauroyl peroxides (BP and LP respectively) at room temperature in non-aqueous media by measuring the volume of released $\mathrm{CO}_{2} . A s$ the decomposition of BP and LP strongly depends on the solvent, the selection of "inert" one was based on preliminary results. Ethyl acetate and tetrachloromethane were used for BPD and LPD, respectively. Among factors that determined the catalytic performance of investigated samples their structural-sorption properties, surface chemistry and diffusion limitation have been considered. It was established that in spite of the high surface area of AC they show moderate catalytic activity comparing to CNT because of internal diffusion limitation. As a consequence, their activity is determined by the textural characteristic of carbon matrices. Catalytic performance of the CNT samples exceeds of AC in 2-20 times. Based on the calculated diffusion coefficients it was concluded that catalysis by CNT is carried out in the kinetic region on their accessible surface. Such catalytically active surface has a lot of $N$ containing functional groups as well as basic O-containing ones, therefore it shows better activity towards organic peroxides. Moreover, CNT's surface is more hydrophobic that is promoting the reaction proceeding in non-aqueous media. The decomposition rate of steric BP is lower compared to the long chain of LP (in both cases of AC and $C N T$ ). Based on this finding, it could be predicted that mesoporous CNT with high content basic functionalities and good surface accessibility should be the excellent catalyst for diacyl peroxides decomposition in organic solvents.
\end{abstract}

Keywords: activated carbon, CNT, benzoyl peroxide, lauroyl peroxide, diffusion, structural-sorption properties, surface chemistry

\section{INTRODUCTION}

Carbon mediated catalysis has been intensively studied from the beginning of XX century. Today carbons with different types of hybridization, such as AC, CNT, graphene, fullerenes, graphite etc. are widely used as catalysts and catalyst supports in acid-base and redox reactions [1-23]. Many researchers report that amorphous carbon (for example, charcoal or AC) is more catalytically active that crystalline one. Such structures have mixed $s p+s p^{2}+s p^{3}$ hybridization carbons and, as a consequence, a more disordered structure that gave a significant increase in the catalytic activity. Nevertheless, crystalline allotropes, such as CNT, graphene, fullerene, also demonstrate excellent catalytic performance [4-11]. It should be noted that pristine carbon structures do not have a sufficient number of reactive sites to be a viable catalyst for most reactions, with the only active sites being located at the unsaturated carbons located at the edges or defects of the graphene layers. However, the catalytic activity of carbons can be greatly enhanced upon introduction of new active sites through either heteroatoms doping or functionalization with organic groups.

The use of carbon materials as catalysts in peroxides decomposition in the aqueous medium, in particular, $\mathrm{H}_{2} \mathrm{O}_{2}$ decay in various buffer solutions, has been the subject of much consideration [12-14]. In contrast, relatively little attention has been paid to degradation of organic peroxides, such as diacyl peroxides with general formula RCOO-OOCR, in non-aqueous media. Benzoyl (BP, $\left.\left(\mathrm{C}_{6} \mathrm{H}_{5} \mathrm{CO}\right)_{2} \mathrm{O}_{2}\right)$ and lauroyl peroxide (LP, $\left.\left(\mathrm{CH}_{3}\left(\mathrm{CH}_{2}\right)_{10} \mathrm{CO}\right)_{2} \mathrm{O}_{2}\right)$ are widely commercial used as a polymerization initiator, especially in medicine, foodstuffs, cosmetics, and rubber industries [15]. It has been shown that BP and LP decomposition (BPD and LPD) reactions are self-induced and depend on temperature and solvent, therefore, the influence 
of these two parameters have been investigated in detail [16-18]. On the other hand, using only solvents and high temperature are not effective because diacyl peroxides are explosive under such conditions. Therefore, catalytic system is more preferable. It should be emphasized that at $25^{\circ} \mathrm{C}$ the uncatalyzed first-order rate constant for BPD is only $5 \times 10^{-9} \mathrm{~s}^{-1}$ [19]. In line with this several studies were conducted and it was shown that the rate of BPD and LPD was greatly accelerated by ferrous or copper ions [20,21]. Nevertheless, using a carbocatalysts for BPD and LPD reactions is not much investigated. M. Yoshida has shown that fullerenes accelerate the reaction of organic peroxides degradation [22]. Several studies have been made with the use of CNT that induce the decomposition of diacyl peroxides with the next functionalization of their surface $[23,24]$.

Recently researchers have highlighted four main carbon's properties that control their catalytic performance: (1) electronic structure, (2) surface chemistry, (3) porosity and (4) thermal stability. Apparently, they all depend on each other and it is impossible to establish separate factor that influences on particular catalytic reaction. Within current investigation, we focus on the influence of textural parameters (surface area, pore size and volume) and the nature of the surface functionalities (oxygen and nitrogen-containing groups) on the catalytic activity of AC and CNT in BPD and LPD reactions. Moreover, for porous materials, diffusion limitation is an important parameter that could significantly influence on the reaction rate. Regarding this considerable attention has been paid to diffusion processes in carbocatalysts. The aim of this study is to investigate the catalytic system "AC/CNT-diacyl peroxide molecule-non-aqueous medium" and determine main factors that influence on carbon catalyst's effectiveness.

\section{MATERIALS AND METHODS}

Carbon catalysts. Initial samples of activated carbon (denoted as $\mathrm{AC}_{\mathrm{ini}}$ ) were obtained by carbonization of apricot stones at the Institute for Sorption and Problem of Endoecology (ISPE, NAS of Ukraine). Oxidized samples $\left(\mathrm{AC}_{\mathrm{ox}}\right)$ were obtained by treatment of $\mathrm{AC}_{\text {ini }}$ with $70 \% \mathrm{w} / \mathrm{w} \mathrm{HNO}_{3}$ at $100{ }^{\circ} \mathrm{C}$ for $4 \mathrm{~h}$, purified from fulvic acids formed upon oxidation by refluxing in $\mathrm{NaOH}$ solution. Regeneration of the protonated form of covalently attached surface acidic groups was carried out by dilute $\mathrm{HCl}$. A treatment of $\mathrm{AC}_{\mathrm{ox}}$ with urea $(10 \% \mathrm{v} / \mathrm{v}$ $\left.\left(\mathrm{NH}_{2}\right)_{2} \mathrm{CO}\right)$ and next drying and further heat treatment in $\mathrm{Ar}$ atmosphere at $700-800^{\circ} \mathrm{C}$ for $1 \mathrm{~h}$ leads to obtaining nitrogen-doped $\mathrm{AC}$ samples (N-AC).

Pristine CNT (Chuiko Institute of Surface Chemistry of NAS of Ukraine) were synthesized by CVD method from a mixture of propylene and hydrogen using a mixed Al-, Fe-, and Mooxide catalyst [25]. After removing the accessible catalyst with $\mathrm{HCl}$ and $\mathrm{NH}_{4} \mathrm{~F}$ solutions, the CNT were washed with distilled water to neutral $\mathrm{pH}$. The samples were kept at $450-500{ }^{\circ} \mathrm{C}$ for $1 \mathrm{~h}$ in air to reduce the amorphous carbon to $3 \%$. The purified CNT samples (labeled as $\mathrm{CNT}_{\text {ini }}$ ) were oxidized in $70 \% \mathrm{w} / \mathrm{w} \mathrm{HNO}_{3}$ at $100{ }^{\circ} \mathrm{C}$ for $4 \mathrm{~h}$ and then washed with distilled water and $\mathrm{NaOH}$ solution for $12 \mathrm{~h}$ [26]. After washing again to neutral $\mathrm{pH}$, the acidic sites were regenerated with $0.1 \mathrm{M} \mathrm{HCl}$ solution. The oven-dried $\left(105^{\circ} \mathrm{C}, 4 \mathrm{~h}\right)$ nanotubes are labeled as $\mathrm{CNT}_{\mathrm{ox}}$. A treatment of $\mathrm{CNT}_{\mathrm{ox}}$ samples with urea according to the above procedure leads to obtaining N-CNT samples with nitrogen incorporated in CNT matrices.

Catalysts characterization. Textural characteristics of investigated samples, such as specific surface area $\left(S_{\mathrm{BET}}, \mathrm{m}^{2} / \mathrm{g}\right)$, sorption volume of pores $\left(\mathrm{Vp}, \mathrm{cm}^{3} / \mathrm{g}\right)$ and pore diameter $\left(d_{\text {pore }}, \mathrm{nm}\right)$ were measured by low-temperature nitrogen adsorption/desorption isotherms using a NOVA 2000e (Quantachrome) automatic analyzer.

The surface chemical composition of the samples was determined by Boehm titration method according to [27] and X-ray photoelectron spectroscopy (XPS). XPS was measured with a VG ESCALAB HP spectrometer, using a non-monochromatized $\mathrm{A} 1 K_{\alpha}$ radiation $(\mathrm{hm}=1486.6 \mathrm{eV}, 200 \mathrm{Wt})$. Wide scan spectra in the binding energy range $0-1100 \mathrm{eV}$ were measured with an energy band-pass of $50 \mathrm{eV}$ for all the samples. Highresolution spectra of the $\mathrm{C} 1 \mathrm{~s}, \mathrm{O} 1 \mathrm{~s}$, and $\mathrm{N} 1 \mathrm{~s}$ signals were recorded in $0.05 \mathrm{eV}$ steps with energy band-pass $20 \mathrm{eV}$. The spectra were referenced with respect to the energy of the $\mathrm{C} 1 s$ line of graphitic carbon ( $s p^{2}$ hybridization) at $284.8 \pm 0.1 \mathrm{eV}$ binding energy (BE). The peak fitting procedure was performed with the CasaXPS program (Version 2.19). After 
subtraction of a Shirley-type baseline, curve fitting was carried out assuming a combined Gaussian (70 \%) and Lorentzian (30\%) peak shape. This technique probes the sample composition to a depth of a few nanometers. Quantitative analysis was performed using areas of XPS peaks corrected for the atomic sensitivity factors (ASF) of the corresponding lines taken from [28]. These are as follows: ASF $(\mathrm{C} 1 s)=0.205, \operatorname{ASF}(\mathrm{N} 1 s)=0.38, \operatorname{ASF}(\mathrm{O} 1 s)=0.63$.

Catalytic assay. Investigation of the catalytic performance of nanoporous and nanosized carbocatalysts was carried out as indicated in [29]. Optimized conditions for catalytic reactions have been obtained earlier and established as: (1) mass of the samples was $0.1 \mathrm{~g}\left(\mathrm{AC}_{\text {ini }}, \mathrm{N}-\mathrm{AC}\right)$, $0.08 \mathrm{~g} \quad\left(\mathrm{AC}_{\mathrm{ox}}\right), 0.01 \mathrm{~g} \quad\left(\mathrm{CNT}_{\mathrm{ox}}\right)$ and $0.005 \mathrm{~g}$ $\left(\mathrm{CNT}_{\text {ini }}\right.$ and $\left.\mathrm{N}-\mathrm{CNT}\right)$ for BPD (concentration of BP was $1-10 \mathrm{v} / \mathrm{v} \%)$; (2) mass of the samples was $0.07 \mathrm{~g}\left(\mathrm{AC}_{\mathrm{ini}}, \mathrm{N}-\mathrm{AC}\right), 0.05 \mathrm{~g}\left(\mathrm{AC}_{\mathrm{ox}}\right), 0.01 \mathrm{~g}$ $\left(\mathrm{CNT}_{\text {ox }}\right)$ and $0.005 \mathrm{~g}\left(\mathrm{CNT}_{\text {ini }}\right.$ and $\left.\mathrm{N}-\mathrm{CNT}\right)$ for LPD (concentration of LP was $1-5 \mathrm{v} / \mathrm{v} \%$ ).

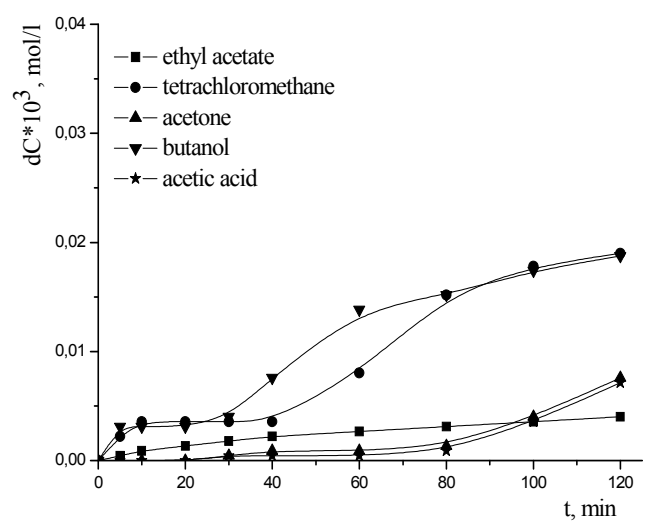

$a$

Fig. 1. Stability of BP $(a)$ and LP $(b)$ in different solvents

\section{RESULTS}

Structural-sorption properties and surface chemistry of carbocatalysts. Table 1 summarizes BET surface area data, showing that AC samples have a surface area greater than CNT in 5-6 times. Neither oxidation nor N-doping processes do not influence on surface area of CNT, but have changed pore diameter and pore volume. All tested carbon samples have well developed mesoporous structure as indicated by average pore diameter, which is between 2 to $50 \mathrm{~nm}$. Pore diameters of CNT are 2-3 times
It should be noted that decomposition of BP and LP strongly depends on the solvent. For determination of the actual (true) rate constant (that refers only to the catalysts) in the reaction system, an inert solvent should be chosen. Therefore, the stability of diacyl peroxides in different solvents has been investigated (Fig. 1). For this purpose, kinetics of the BP $(1 \mathrm{v} / \mathrm{v} \%)$ and LP $(5 \mathrm{v} / \mathrm{v} \%)$ decomposition in the different solvents have been measured as $\mathrm{d} C=\mathrm{f}(t)$, where $\mathrm{d} C=\left[\ln \left(1 /\left(1-C_{\mathrm{t}}\right)\right)\right] / m,\left(C_{\mathrm{t}}-\right.$ concentration of the peroxide at the moment $t, m-$ mass of the catalyst $(m=1$ in case of stability experiments investigation)). Among tested solvents, ethyl acetate (EA) and tetrachloromethane (TCM) were almost inactive towards BPD and LPD and have been used as non-aqueous media in catalytic measurements. The rate constants calculation, as well as detailed diffusion coefficients determination, was carried out as indicated elsewhere [29].

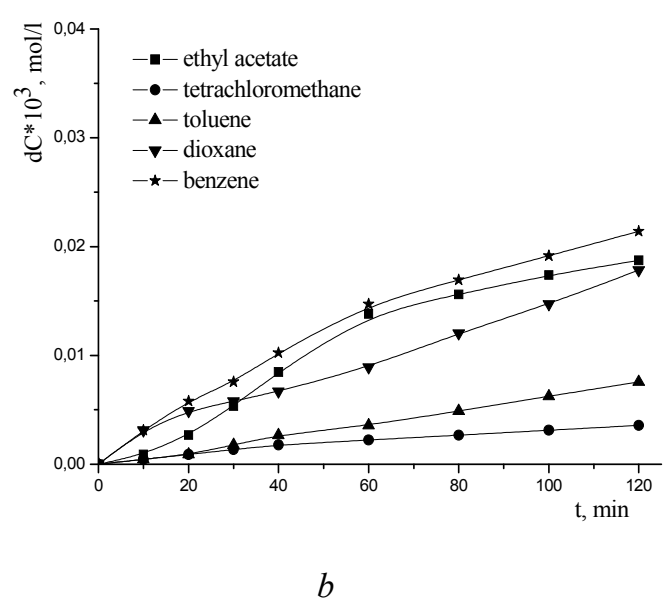

greater than such value for $\mathrm{AC}$; what is more interesting - space between the nanotubes and their aggregates corresponds to meso- and macropores (as has been established earlier [30]).

Surface chemistry characteristics are presented in Table 2. According to the elemental analysis data, initial AC sample mainly consists of carbon atoms. Apricot originated activated carbon could have a small amount of nitrogen in its structure. Nitric acid oxidation, as well as urea treatment, lead to significant increase of $\mathrm{O}$ and $\mathrm{N}$ elements. It is worth noting that, 
according to Boehm titration, $\mathrm{O}$ element is the part of acidic groups in $\mathrm{AC}_{\mathrm{ox}}$ sample and basic groups (carbonyl, quinone) in N-AC sample. Regarding this, it could be concluded that urea treatment leads not only to $\mathrm{N}$-doping ( $\mathrm{N}$ content increases in 4 times) of carbon matrices but also to the partial reduction of acidic groups. CNT react in another way - the content of hydrogen was approximately 1 at. $\%$ in $\mathrm{CNT}_{\text {ini }}$ and $\mathrm{CNT}_{\mathrm{ox}}$, and decreased to 0.1 at. $\%$ for N-CNT. This observation can be explained by dehydrogenation properties of urea [31]. Pristine CNT that are not stored under special conditions always contain O-functionalities, since the active edges and defects sites react readily with oxygen from the atmosphere. In contrast to $\mathrm{AC}$, urea treatment doesn't lead to increasing of $\mathrm{N}$-content in CNT, but only reduces the amount of O-containing groups.

Table 1. Textural characteristics of carbon catalysts

\begin{tabular}{cccc}
\hline Sample & $\boldsymbol{S}_{\text {BET }}, \mathbf{~ m}^{\mathbf{2}} / \mathbf{g}$ & $\boldsymbol{V}_{\mathbf{p}}, \mathbf{c m}^{\mathbf{3}} \mathbf{g}$ & $\boldsymbol{d}_{\text {pore }}, \mathbf{n m}$ \\
\hline $\mathrm{AC}_{\text {ini }}$ & 920 & 0.50 & 3.55 \\
$\mathrm{AC}_{\text {ox }}$ & 790 & 0.85 & 3.70 \\
$\mathrm{~N}-\mathrm{AC}$ & 940 & 0.91 & 4.00 \\
$\mathrm{CNT}_{\text {ini }}$ & 145 & 0.48 & 8.00 \\
$\mathrm{CNT}_{\text {ox }}$ & 150 & 0.56 & 11.00 \\
$\mathrm{~N}-\mathrm{CNT}$ & 145 & 0.31 & 12.00 \\
\hline
\end{tabular}

Table 2. Surface chemistry characteristics of carbocatalysts

\begin{tabular}{cccccccccc}
\hline Sample & \multicolumn{3}{c}{ Elemental analysis, at. \% } & \multicolumn{5}{c}{ Boehm titration, group, mmol/g } \\
\cline { 2 - 10 } & $\mathbf{C}$ & $\mathbf{H}$ & $\mathbf{O}$ & $\mathbf{N}$ & Carboxylic & Lactonic & Phenolic & Basic & $\begin{array}{c}\text { Total } \\
\text { acidic }\end{array}$ \\
\hline $\mathrm{AC}_{\text {ini }}$ & 99.4 & 0.2 & 0.1 & 0.3 & 0.04 & 0.06 & 0.02 & n.d. & 0.12 \\
$\mathrm{AC}_{\mathrm{ox}}$ & 96.3 & 1.1 & 2.1 & 0.5 & 0.84 & 0.20 & 1.39 & n.d. & 2.43 \\
$\mathrm{~N}-\mathrm{AC}$ & 89.2 & 2.3 & 6.3 & 2.2 & n.d. & 0.45 & 0.05 & 1.90 & 0.50 \\
$\mathrm{CNT}_{\text {ini }}$ & 96.1 & 0.7 & 3.2 & n.d. & 0.10 & 0.31 & 0.03 & 0.23 & 0.44 \\
$\mathrm{CNT}_{\text {ox }}$ & 95.2 & 1.0 & 3.4 & 0.39 & 0.40 & 0.40 & 0.55 & n.d. & 1.35 \\
$\mathrm{~N}-\mathrm{CNT}$ & 99.0 & 0.1 & 0.5 & 0.41 & 0.41 & 0.22 & 0.09 & n.d. & 0.72 \\
\hline
\end{tabular}

Fig. 2 shows the XPS O1s spectra of investigated samples. They were deconvoluted into four peaks (Table 3). Because of different information in the literature, we omitted peak $A(530.2 \pm 0.2 \mathrm{eV})$; other peaks correspond to carbonyl and quinone groups, as well as to oxidized nitrogen $(B, \quad 531.2 \pm 0.5 \mathrm{eV})$, hydroxyl and anhydride $(C, 532.5 \pm 0.2 \mathrm{eV})$ and carboxylic acid groups $(D, 533.1 \pm 0.5 \mathrm{eV})$ [32].

Initial AC sample has mainly basic O-containing groups (carbonyl and quinone). Oxidation by nitric acid leads to the appearance of the acidic O-containing groups (carboxylic acid) and increasing of hydroxyl and anhydride groups in 4 times. $\mathrm{N}$-doped AC contains equally basic/acidic groups without carboxylic ones on its surface. Initial CNT sample also has some amount of basic $\mathrm{O}$-containing groups as well as carboxylic ones. Further oxidation of CNT leads to the appearance of hydroxyl and anhydride (from $\mathrm{COOH}$ ) groups. Urea acts as a reducing agent because of increasing of basic O-containing groups.

Apparently, oxidation with nitric acid also leads to an increase in nitrogen content. Fig. 3 and Table 4 show the N1s XPS results of the obtained samples, all of which have five different types of N1s features: $\mathrm{P}_{1}$ at $397.2 \mathrm{eV}, \mathrm{P}_{2}$ at $398.6 \mathrm{eV}, \quad \mathrm{P}_{3}$ at $400.8 \mathrm{eV}, \quad \mathrm{P}_{4}$ at $402.3-403.1 \mathrm{eV}, \mathrm{P}_{5}$ at $404.6-406.2 . \mathrm{P}_{5}$ originates from $\mathrm{NO}_{\mathrm{x}}$ group, where $\mathrm{P}_{4}$ from the pyridine-Noxide structure [1]. $\mathrm{P}_{3}$ originates from quaternary $\mathrm{N}$ atoms, that will be equivalent to positively charged $\mathrm{N}$ atoms like in the ammonium ion $\left(\mathrm{NH}_{4}{ }^{+}\right)[33,34]$. We have found that peak $\mathrm{P}_{2}$ can be assigned for pyridine-like nitrogen coordination [34-36]. We do not attempt to assign the first peak owing to the contradictory information in the literature. 


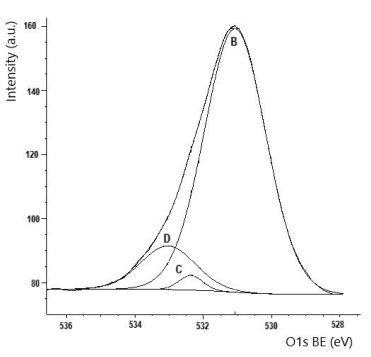

$a$

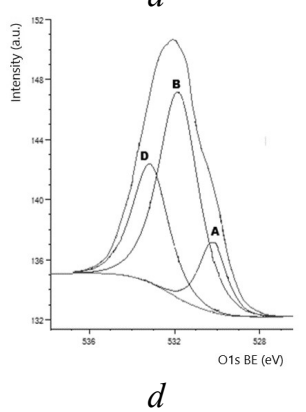

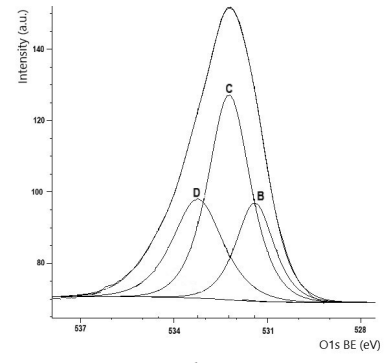

$b$

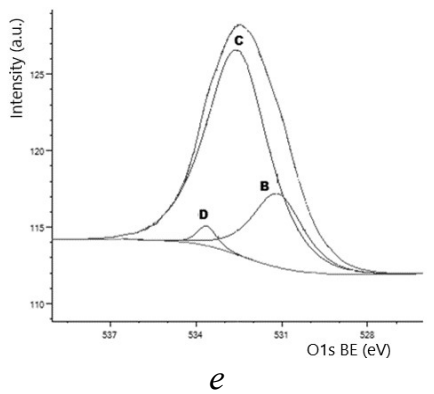

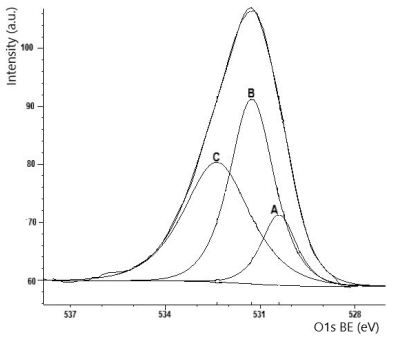

$c$

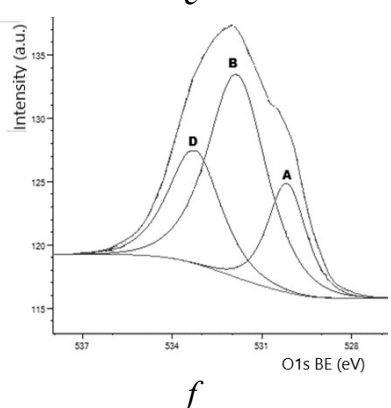

Fig. 2. Deconvolution of the $\mathrm{O} 1 s$ bands of $\mathrm{AC}_{\text {ini }}(a), \mathrm{AC}_{\mathrm{ox}}(b), \mathrm{N}-\mathrm{AC}(c), \mathrm{CNT}_{\text {ini }}(d), \mathrm{CNT}_{\mathrm{ox}}(e), \mathrm{N}-\mathrm{CNT}(f)$

Table 3. Distribution (\%) of the O1s binding states

\begin{tabular}{|c|c|c|c|c|}
\hline Binding energy, eV & $\begin{array}{c}A \\
530.2 \pm 0.2\end{array}$ & $\begin{array}{c}\text { B } \\
531.2 \pm 0.5\end{array}$ & $\begin{array}{c}C \\
532.5 \pm 0.2\end{array}$ & $\begin{array}{c}D \\
533.1 \pm 0.5\end{array}$ \\
\hline $\mathrm{AC}_{\mathrm{ini}}$ & - & 85.60 & 12.6 & 1.80 \\
\hline $\mathrm{AC}_{\mathrm{ox}}$ & - & 19.80 & 46.0 & 34.20 \\
\hline N-AC & 13.30 & 44.20 & 42.5 & - \\
\hline $\mathrm{CNT}_{\text {ini }}$ & 13.35 & 56.90 & - & 29.75 \\
\hline $\mathrm{CNT}_{\text {ox }}$ & - & 22.45 & 75.3 & 2.25 \\
\hline $\mathrm{N}-\mathrm{CNT}$ & 19.20 & 53.70 & - & 27.30 \\
\hline
\end{tabular}

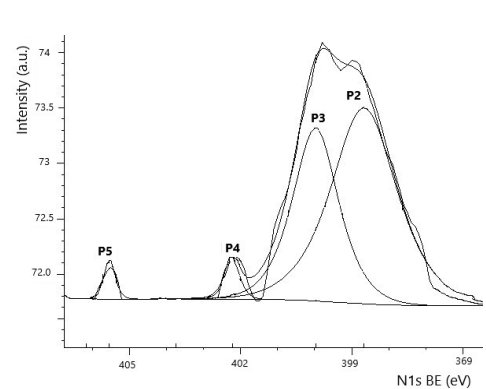

$a$

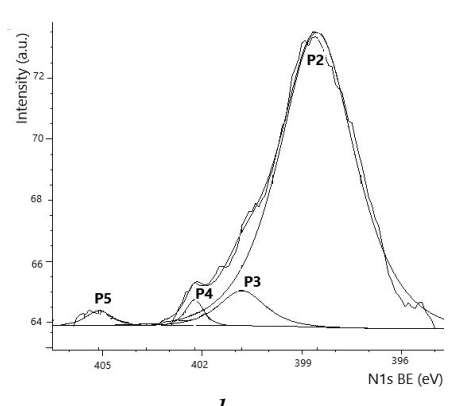

$b$

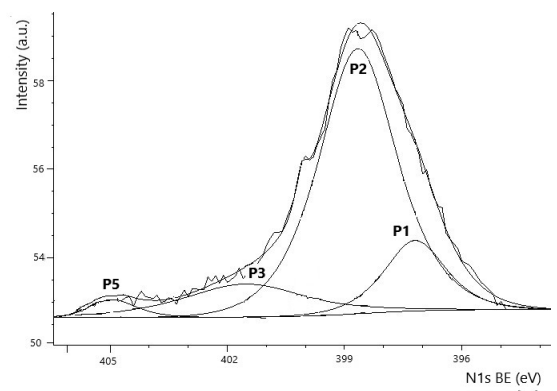

$c$
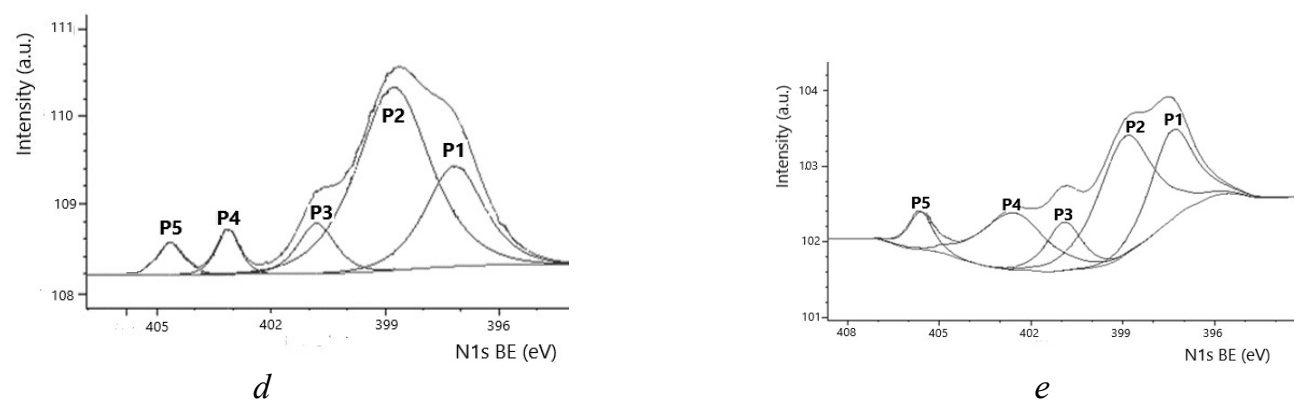

Fig. 3. Deconvolution of the $\mathrm{N} 1 s$ bands of $\mathrm{AC}_{\mathrm{ini}}(a), \mathrm{AC}_{\mathrm{ox}}(b), \mathrm{N}-\mathrm{AC}(c), \mathrm{CNT}_{\mathrm{ox}}(d), \mathrm{N}-\mathrm{CNT}(e)$ 
As for oxygen, nitrogen-containing functionalities determine the acidic and basic character of carbons and thus its surface chemical reactivity and catalytic activity. Lactams, imides, and amines are slightly acidic in their nature, but they are not presented in tested samples. On the other hand, N quaternary, pyridinic and pyrrole-type structures are responsible for basicity of the surface as well as for increasing surface polarity. Table 4 clearly shows that all samples have only basic N-groups in their structure.

It worth to note that a large number of O-containing acidic groups on carbon surface overshadow the contribution of resonating electrons to carbon basicity. Therefore, samples with the same amount of $\mathrm{N}$-containing groups but a different number of O-containing groups could have absolutely different catalytical properties. This assumption will be proved in the next paragraphs.

Table 4. Distribution (\%) of the N1s binding states

\begin{tabular}{cccccc}
\hline \multirow{2}{*}{ Binding energy, eV } & $\mathbf{P}_{\mathbf{1}}$ & $\mathbf{P}_{\mathbf{2}}$ & $\mathbf{P}_{\mathbf{3}}$ & $\mathbf{P}_{\mathbf{4}}$ & $\mathbf{P}_{\mathbf{5}}$ \\
\cline { 2 - 6 } & $\mathbf{3 9 7 . 2 + 0 . 2}$ & $\mathbf{3 9 8 . 6 + 0 . 3}$ & $\mathbf{4 0 0 . 8}+\mathbf{0 . 4}$ & $\mathbf{4 0 2 . 3}-\mathbf{4 0 3 . 1}$ & $\mathbf{4 0 4 . 6 - 4 0 6 . 2}$ \\
\hline $\mathrm{AC}_{\mathrm{ini}}$ & - & 57.60 & 35.6 & 4.00 & 2.80 \\
$\mathrm{AC}_{\mathrm{ox}}$ & - & 89.30 & 6.40 & 2.80 & 1.50 \\
$\mathrm{~N}-\mathrm{AC}$ & 14.20 & 67.40 & 14.30 & - & 4.10 \\
$\mathrm{CNT}_{\text {ox }}$ & 25.37 & 57.35 & 8.00 & 4.47 & 4.81 \\
$\mathrm{~N}-\mathrm{CNT}$ & 22.95 & 39.29 & 10.35 & 21.96 & 5.45 \\
\hline
\end{tabular}

Catalytic performance of $A C$ and CNT. The catalytic performance of carbocatalysts in the decomposition reaction of organic peroxides is characterized i Fig. 4. According to the results obtained (Table 5), all carbon samples show moderate catalytic activity in organic solvents. Calculated rate constants imply that

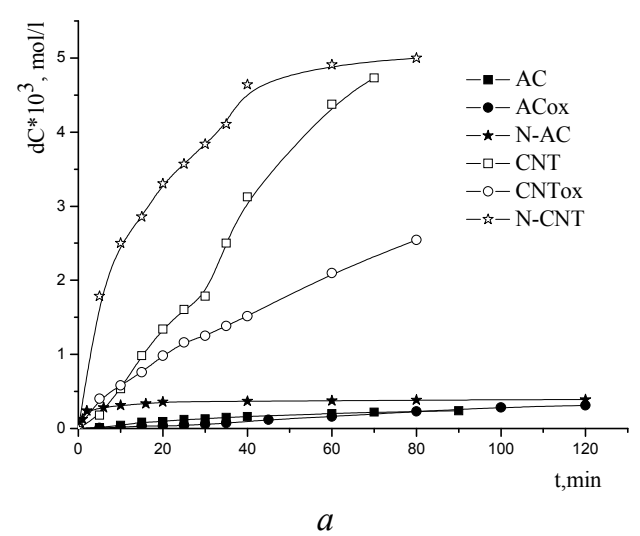

Fig. 4. Decomposition of $\mathrm{BP}(a)$ and $\mathrm{LP}(b)$ over carbocatalysts at $25^{\circ} \mathrm{C}\left(C_{\text {in }}(\mathrm{BP}, \mathrm{LP})-5 \%\right)$

As follows from Fig. 4, introducing of nitrogen in carbonaceous matrices significantly increases the rate of BPD and LPD reactions. As indicated by the data shown in Table 5, N-AC samples exhibit the best catalytic activity in BPD as well as LPD and is in 2.5-4 times more active than $\mathrm{AC}_{\mathrm{ini}} / \mathrm{AC}_{\mathrm{ox}}$ samples. The same tendency is nanostructured carbon (CNT) are more active than traditional $\mathrm{AC}$ and outperform their catalytic activity in 6 times in case of BPD, and 8 times - LPD reactions. Moreover, the activity of CNT in LPD in 3-10 times outreaches than in BPD.

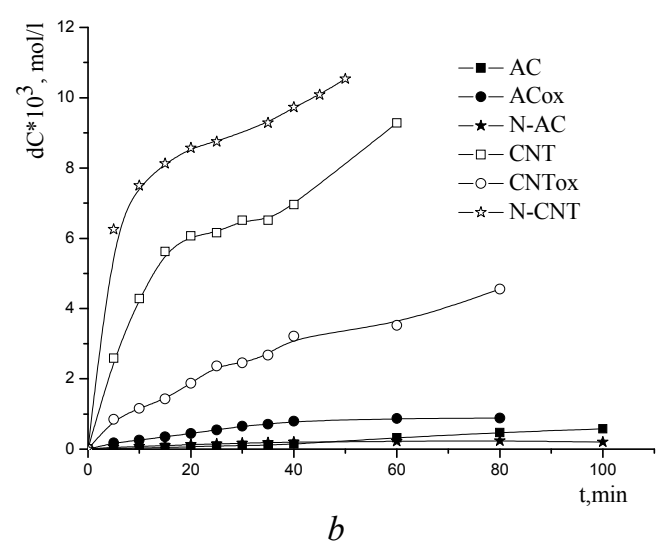

observed for $\mathrm{CNT}$ and their activity increase in the raw: $\mathrm{N}-\mathrm{CNT}>\mathrm{CNT}_{\text {ini }}>\mathrm{CNT}_{\text {ox }}$.

The observation that $\mathrm{N}$-doped carbons are effective in peroxides decomposition is commonly known. What is interesting in the current investigation - why AC samples with a large surface are less active than CNT. To gain 
more insight into the different factors that contribute to carbon materials for peroxides decomposition in organic solvents, we firstly analyzed diffusion limitations that could influence the catalytic performance.

Table 5. Rate constants of peroxides decomposition $\left(k \times 10^{-4}, \mathrm{~s}^{-1}\right)$

\begin{tabular}{ccc}
\hline Sample & BP & LP \\
\hline $\mathrm{AC}_{\text {ini }}$ & 0.0066 & 0.006 \\
$\mathrm{AC}_{\text {ox }}$ & 0.0015 & 0.008 \\
$\mathrm{~N}-\mathrm{AC}$ & 0.0290 & 0.021 \\
$\mathrm{CNT}_{\text {ini }}$ & 0.0220 & 0.180 \\
$\mathrm{CNT}_{\text {ox }}$ & 0.0140 & 0.098 \\
$\mathrm{~N}-\mathrm{CNT}$ & 0.0600 & 0.460 \\
\hline
\end{tabular}

Diffusion limitation. As mentioned above diffusion phenomena could take an important part of the catalytic process and determined the catalytic ability of porous catalysts. Regarding this, diffusion coefficients for tested reactions were calculated (Table 6). Calculated Da numbers are much less than unity that allows us to conclude that reactions proceed via molecular nature on external, accessible surface of the investigated samples. Moreover, obtained results clearly show that for AC samples investigated reactions limited by internal diffusion because of $D_{\text {eff }}$ is much less than the reaction rate. In contrast, reactions of BPD and LPD catalyzed by CNT carried out in the kinetic region and doesn't limit by internal diffusion $\left(D_{\text {eff }}>\right.$ or $\left.\sim r\right)$.

Table 6. Damkohler number $(D a)$, reaction rate $\left(r \times 10^{-10} \mathrm{~mol} /\left(\mathrm{s} \times \mathrm{m}^{2}\right)\right)$ and diffusion coefficient $\left(D_{\text {eff }} \times 10^{-10} \mathrm{~m}^{2} / \mathrm{s}\right)$ values of BPD and LPD at $25{ }^{\circ} \mathrm{C}$ over AC and CNT

\begin{tabular}{ccccccc}
\hline \multirow{2}{*}{ Sample } & \multicolumn{3}{c}{$\mathbf{B P}$} & \multicolumn{1}{c}{$\mathbf{L P}$} \\
\cline { 2 - 7 } & $\boldsymbol{D a}$ & $\boldsymbol{r}$ & $\boldsymbol{D}_{\text {eff }}$ & $\boldsymbol{D a}$ & $\boldsymbol{r}$ & $\boldsymbol{D}_{\text {eff }}$ \\
\hline $\mathrm{AC}_{\text {ini }}$ & $<<1$ & 0.091 & 0.00148 & $<<1$ & 0.039 & 0.00082 \\
$\mathrm{AC}_{\text {ox }}$ & $<<1$ & 0.019 & 0.00031 & $<<1$ & 0.121 & 0.00550 \\
$\mathrm{~N}_{\mathrm{AC}}$ & $<<1$ & 0.059 & 0.00014 & $<<1$ & 0.085 & 0.00110 \\
$\mathrm{CNT}_{\text {ini }}$ & 0.0004 & 31.3 & 53.2 & 0.0039 & 102.5 & 179.7 \\
$\mathrm{CNT}_{\text {ox }}$ & 0.0003 & 40.2 & 32.6 & 0.0022 & 82.1 & 212.8 \\
$\mathrm{~N}-\mathrm{CNT}$ & $<<1$ & 22.1 & 95.7 & 0.0008 & 88.1 & 53.2 \\
\hline
\end{tabular}

\section{DISCUSSION}

Influence of textural characteristics on catalytic performance of carbocatalysts. Tables 1 and 5 clearly demonstrate that activity of AC strict relates to surface area and pore diameter. It was not surprising, because BPD and LPD's reaction rate is defined by internal diffusion of molecules of peroxides to the active centers of catalysts. However, for CNT such relationship was not observed. Any correlation between $S_{\mathrm{BET}}$ and $V_{\mathrm{p}}$ and their catalytic performance was not obtained. The catalytic activity of CNT in BPD and LPD increases in a row $\mathrm{N}-\mathrm{CNT}>\mathrm{CNT}_{\text {ini }}>\mathrm{CNT}_{\text {ox }}$ with no any $S_{\mathrm{BET}}$ changing.

Comparing of the two different carbon structures (3D a structure of AC and rolled 2D structure of the CNT) it should be noted that catalytic activity of CNT samples is outperformed of AC samples in several times. In particular, the rate constant of N-CNT is in 2 times more than that of N-AC in case of BPD and in 20 times more in case of LPD ones. Obviously, such behavior couldn't be explained only by different structural and electronic characteristics of the sample. According to the calculated $D_{\text {eff }}$, it is clear that diffusion limitation takes a key role in the organic peroxides decomposition on the carbonaceous matrices. Apparently, the only high value of $S_{\mathrm{BET}}$ is not enough for catalysis if it is proceeding in the diffusion region. Accessibility of the "active surface", that have a lot of catalytic centers is the main factor that determined good catalytic activity. Hence, the catalytic reaction that is 
conducted in the kinetic diffusion region is more effective (even in case of poor $S_{\mathrm{BET}}$ value) than that limited by internal diffusion.

Influence of surface functional groups on catalytic performance of $A C$ and CNT. It is generally known, that catalysis on the solid surface is specified not only by the accessibility of the surface but also by the structure of the catalytic centers. Both types of samples have been modified in the same way. However, their surface chemistry content is different (Table 3,4 ). As expected, the catalytic activity of carbon matrices in non-aqueous medium benefits from the increasing of nitrogen-containing electron donor groups and increases in the row (as for BPD as well as for LPD): Nitrogen-doped carbon $>$ Initial carbon $>$ Oxidized carbon. Commonly, the insertion of nitrogen atoms into the graphite lattice lowers the band gap, leading to higher electron mobility and lowering work function at the carbon/fluid interaction. Besides graphitic nitrogen atoms that are very important for catalyzing of BPD and LPD, unusual effect displayed by catalytic quantities of nitro compounds [37], $\mathrm{NH}_{2}$-groups and morpholine type structures on carbon surface $[38,39]$. Comparing the total amount of nitrogen for AC and CNT, it could be concluded that urea treatment doesn't have an influence on the nitrogen content for CNT and increases it in 4 times for AC. Meanwhile, no correlation between different N-groups (Table 4) and catalytic activity was found.

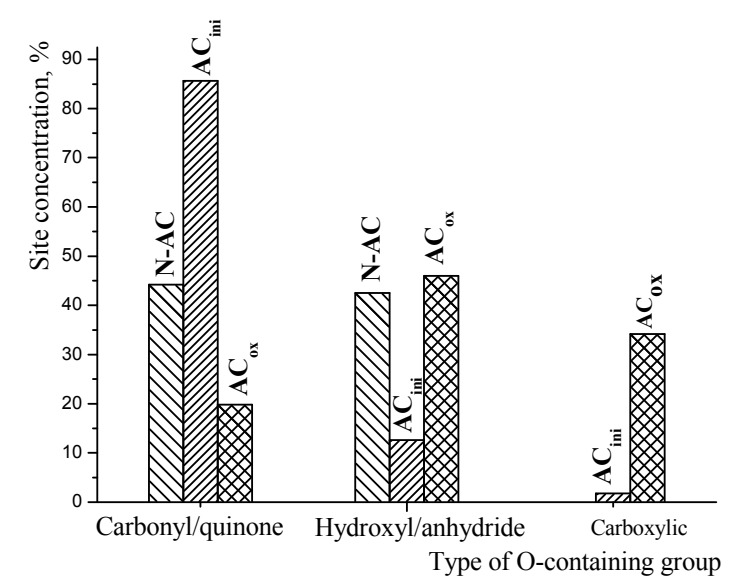

Simultaneously, a high concentration of the O-containing groups has a strong inhibiting effect on BPD and LPD reactions. Modification of carbon matrice with electron withdrawing oxygenated groups decreases delocalized $\pi$ electrons on the surface and, as consequence, the surface electron density of it is lower than that of $\mathrm{N}$-doped one. Therefore, as $\mathrm{AC}_{\mathrm{ox}}$ as well as $\mathrm{CNT}_{\text {ox }}$ with higher acidic character performs a lower catalytic activity. However, not all types of O-containing groups have such influence on the catalysis by $\mathrm{AC}(\mathrm{CNT})$. It has been established earlier [29] that catalytic activity of CNT in nonaqueous medium also could be defined by basic O-containing groups (carbonyl/quinone) that interact with the solid surface according to single-electron transfer (SET) mechanism. From the Fig. 5 it is clear that N-CNT sample has the smallest amount of acidic O-containing groups (hydroxyl, anhydride, and carboxylic) and a lot of basic ones (carbonyl/quinone). On another note, for the AC samples, such tendency is not observed. Initial $\mathrm{AC}$ has a large amount of carbonyl/quinone groups and lower activity than $\mathrm{N}-\mathrm{AC}$. In the same time, it has acidic O-containing groups that disrupt the $\pi$-conjugation and introduce surface dipole moments, leading to higher work functions. Such phenomena overshadow the contribution of resonating electrons to carbon basity. Moreover, the amount of nitrogen on the AC surface is in 4 times lower, than that on the N-AC.

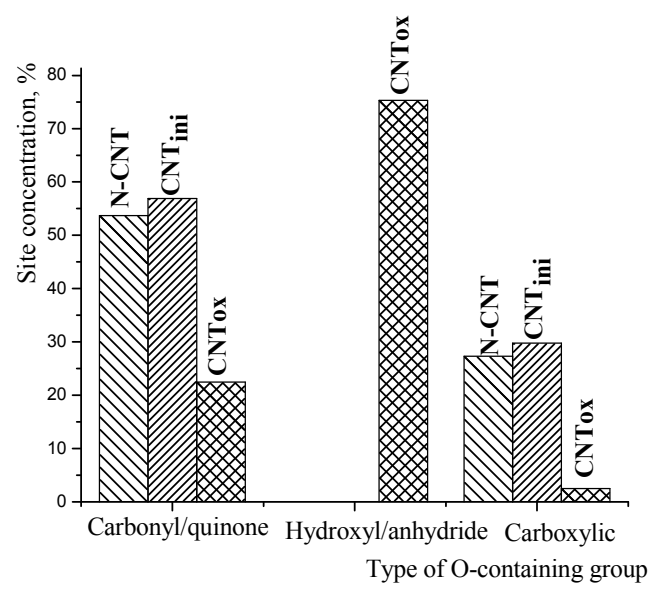

Fig. 5. Amount of O-containing groups (O1s XPS data) of AC and CNT

Obtained results also revealed that decomposition rate of steric BP is lower compared to the long chain of LP (in both cases of $\mathrm{AC}$ and CNT). Probably, LP could easier (than BP) penetrates into the long-range order cavity of the tubes with good electron 
localization and functional groups along the tube that is preferred for the reaction. Moreover, according to [40], decomposition of acyl peroxides proceeds through transition complex; stability of that depends on reaction viscosity. Increasing solvent viscosity $(0.43 \mathrm{cps}$ for EA compared to $0.95 \mathrm{cps}$ for TCM) leads to rising of the transition complex stability and, as consequence, to decreasing of the activation barrier of reaction and better catalytic activity in LPD.

\section{CONCLUSIONS}

Metal-free carbocatalysts could be an effective alternative for the peroxides decomposition in nonaqueous media because they are inexpensive and non-toxic. Specific porous structure, the presence of surface functional spices and surface basicity significantly influence catalytic performance. High surface area and porosity are required for effective activity, but not sufficient. Accessibility of the "active surface" (without any diffusion limitation), that have a lot of catalytic centers also is an important factor that determined good catalytic activity. In addition, carbon surface must have a high concentration of electron donor functionalities. Based on this finding, it could be predicted that mesoporous CNT with high content basic functionalities could be the excellent catalyst for diacyl peroxides decomposition in organic solvents.

\title{
Каталітичне розкладання органічних пероксидів в неводному середовищі нанопоруватими та нанорозмірними вуглецевими матеріалами
}

\author{
К.В. Войтко, О.М. Бакалінська, Картель М.Т. \\ Інститут хімії поверхні ім. О.О. Чуйка Національної академії наук Украӥни \\ вул. Генерала Наумова, 17, Київ, 03164, Україна, kvoitko@gmail.com
}

\begin{abstract}
Метою роботи є дослідження каталітичної системи “Вуглецевий наноматеріал - молекули діацил пероксиду у неводному середовищі” та встановлення основних факторів, щзо впливають на каталітичну активність обраних матеріалів. Досліджено каталітичну активність нанопоруватих (активованого вугілля (AB)) та нанорозмірних (багатошарових вуглецевих нанотрубок (ВНТ)) вуглецевих каталізаторів та їхніх модифікованих форм в реакції розкладання пероксидів бензоїлу та лаурилу (ПБ та ПЛ відповідно) при кімнатній температурі у неводному середовищі иляхом вимірювання об'єму $\mathrm{CO}_{2}$, щуо виділяється. Оскільки розкладання пероксидів залежить від розчинника, вибір «інертного» зроблено за результатами попередніх досліджень. Етилацетат та тетрахлорметан було використано для ПБ та ПЛ, відповідно. Серед факторів, щзо визначають каталітичну ефективність досліджуваних зразків були розглянуті їхні структурно-сорбційні властивості, хімія поверхні та дифузійні параметри перебігу реакцій. Встановлено, що незважаючи на високу площу поверхні, зразки АВ виявляють помірну каталітичну активність у порівнянні з ВНТ, оскільки реакиія проходить у внутрішньодифузійній області. Як наслідок, їхня активність визначається текстурними характеристиками вуглецевої матриці. Каталітична активність зразків ВНТ перевищує активність $A B$ в 2-20 разів. Ірунтуючись на розрахованих коефіцієнтах дифузії, було зроблено висновок, щчо каталіз зразками ВНТ проходить в кінетичній області на доступній поверхні зразків. Така каталітично активна поверхня містить багато $N$-вмісних та основних O-вмісних функціональних груп, тому демонструє кращу каталітичну активність щчодо розкладання органічних пероксидів. Крім того, поверхня ВНТ більш гідрофобна, щчо сприяє реакиії, яка проходить у неводних середовищах. Слід зазначити, щзо швидкість розкладання стеричного ПБ нижча, ніж довголанцюгового ПЛ, як у випадку прискорення зразками АВ, так і ВНТ. На основі проведених досліджень можна передбачити, щзо мезопоруваті ВНТ з високим вмістом основних функціональних груп, щзо знаходяться на доступній для субстрату поверхні, можуть бути гарною альтернативою поширеним каталізаторам розкладання органічних пероксидів в неводних середовищзах.
\end{abstract}

Ключові слова: ативоване вугілля, вуглецеві нанотрубки, бензоїл пероксид, лаурил пероксид, дифузія, структурно-сорбиійні характеристики, хімія поверхні 


\title{
Каталитическое разложение органических пероксидов в неводных средах нанопористыми и наноразмерными углеродными катализаторами
}

\author{
Е.В. Войтко, О.Н. Бакалинская, Н.Т. Картель
}

Институт химии поверхности им. А.А. Чуйко Наџиональной академии наук Украины ул. Генерала Наумова, 17, Киев,03164, Украина, kvoitko@gmail.com

\begin{abstract}
Цель работы - исследование каталитической системы “Уалеродный наноматериал - молекуль диацил пероксида в неводной середе” и определение основных факторов, которые влияют на каталитическую активность выбранных материалов. Изучена каталитическая активность нанопористых (активированного угля (АУ)) и наноразмерных (многослойных углеродных нанотрубок (УНТ)) углеродных катализаторов и их модифицированных форм в реакции разложения пероксидов бензоила и лаурила (ПБ и ПЛ соответственно) при комнатной температуре в неводной среде измерением объема выделившегося СО. Поскольку разложение пероксидов зависит от растворителя, выбор «инертного» осуществлен по результатам предварительных исследований. Этилацетат и тетрахлорметан использовали для ПБ и ПЛ, соответственно. Среди факторов, определяющих каталитическую эффективность исследуемых образцов, были рассмотрены их структурно-сорбционные свойства, химия поверхности и диффузионные параметры проведения реакций. Установлено, что несмотря на высокую площадь поверхности, АУ демонстрируют умеренную каталитическую активность по сравнению с УНТ, поскольку реакиия проходит во внутридиффузионной области. Как следствие, их активность определяется текстурными характеристиками углеродной матрицы. Каталитическая активность образиов УНТ превосходит активность АУ в 2-20 раз. Основываясь на рассчитанных коэффициентах диффузии, был сделан вывод, что катализ образцами УНТ проходит в кинетической области на доступной поверхности образцов. Такая каталитически активная поверхность содержит много $N$-содержащих и основных О-содержащих функииональных групп, поэтому демонстрирует лучшую каталитическую активность в отношении разложения органических пероксидов. Кроме того, поверхность УНТ является более гидрофобной, что способствует реакции, которая проходит в неводных средах. Следует отметить, что скорость разложения стерического ПБ ниже, чем длинноцепочечного ПЛ, как в случае ускорения образцами АУ, так и УНТ. На основе проведенных исследований можно предположить, что мезопористые УНТ с высоким содержанием основных функциональных групп, находящихся на доступной для субстрата поверхности, могут быть хорошей альтернативой распространенным катализаторам разложения органических пероксидов в неводных средах.
\end{abstract}

Ключевые слова: активированный уголь, углеродные нанотрубки, бензоил пероксид, лаурил пероксид, диффузия, структурно-сорбционные характеристики, химия поверхности

\section{REFERENCES}

1. Serp P., Machado B. Nanostructured Carbon Materials for Catalysis. (Cambridge: The Royal Society of Chemistry, 2015).

2. Dreyer R.D., Bielawski C.W. Carbocatalysis: Heterogeneous carbons finding utility in synthetic chemistry. Chem. Sci. 2011. 2: 1233.

3. Figueiredo J.L., Pereira M.F.R. Carbon Materials for Catalysis. (NY: John Wiley \& Sons, 2009).

4. Hermenegildo G. Allotropic carbon nanoforms as advanced metal-free catalysts or as supports. Adv. Chem. 2014. 2014: ID 906781.

5. Yu H., Peng F., Tan J., Hu X., Wang H., Yang J., Zheng W. Selective catalysis of the aerobic oxidation of cyclohexane in the liquid phase by carbon nanotubes. Angew. Chem. Int. Ed. 2011. 50(17): 3978.

6. Bégin D., Ulrich G., Amadou J., Su D.S., Pham-Huu C., Ziessel R. Oxidative dehydrogenation of 9,10dihydroanthracene using multi-walled carbon nanotubes. J. Mol. Catal. A. 2009. 302(1-2): 119.

7. Chua C.K., Pumera M. Carbocatalysis: The state of "metal-free" catalysis. Chem. Eur. J. 2015. 21(36): 12550.

8. Navalon S., Dhakshinamoorthy A., Alvaro M., Garcia H. Carbocatalysis by graphene-based materials. Chem. Rev. 2014. 114(12): 6179.

9. Su C., Loh K.P. Carbocatalysts: graphene oxide and its derivatives. Acc. Chem. Res. 2013. 46(10): 2275.

10. Shi Y., Gan L., Wei X., Jin S., Zhang S., Meng F., Wang Z., Yan C. Fullerene-sensitized. Org. Lett. 2000. 2(5): 667. 
11. Pacosová L., Kartusch C., Kukula P., Bokhoven J.A. Is fullerene a nonmetal catalyst in the hydrogenation of nitrobenzene. Chem. Cat. Chem. 2011. 3(1): 1541.

12. Oliveira L.C.A., Silva C.N., Yoshida M.I., Lago R.M. The effect of $\mathrm{H}_{2}$ treatment on the activity of activated carbon for the oxidation of organic contaminants in water and the $\mathrm{H}_{2} \mathrm{O}_{2}$ decomposition. Carbon. 2004. 42(11): 2279.

13. Khalil L.B., Girgis B.S., Tawfik T.A. Decomposition of $\mathrm{H}_{2} \mathrm{O}_{2}$ on activated carbon obtained from olive stones. J. Chem. Technol. Biothechnol. 2001. 76(11): 1132.

14. Voitko K., Whitby R.L.D., Gun'ko V., Bakalinska O.M., Kartel M.T., Laszlo K., Cundy A.B., Mikhalovsky S.V. Morphological and chemical features of nano and macroscale carbons affecting hydrogen peroxide decomposition in aqueous media. J. Colloid Interface Sci. 2011. 361(1): 129.

15. Sun C., Yan G., Lin X., Ma S., Li Z. Theoretical studies on thermal decomposition of benzoyl peroxide in ground state. Chem. Res. Chinese Univer. 2003. 19: 355.

16. Ying Y., Saini R.K., Liang F., Sadana A.K., Billups W.E. Functionalization of carbon nanotubes by free radicals. Org. Lett. 2003. 5(9): 1471.

17. Walling C., Waits H.P., Milovanovic J., Pappiaonnou C.G. Polar and radical paths in the decomposition of diacyl peroxides. J. Am. Chem. Soc. 1970. 92(16): 4927.

18. Lyavinets A.S. Kinetic features of decomposition of benzoyl peroxide in superbasic media. Rus. J. Gen. Chem. 2005. 75(5): 759 .

19. Smith W.F., Rossiter B.W. Induced decomposition of benzoyl peroxide by the benzophenone ketyl radical. Tetrahedron. 1969. 25(10): 2059.

20. Hasegawa S., Nishimura N. Studies on organic peroxides. V. Decomposition of benzoyl peroxide by iron(II). Bull. Chem. Soc. Jap. 1960. 33(6): 775.

21. Kochi J.K. The Decomposition of peroxides catalyzed by copper compounds and the oxidation of alkyl radicals by cupric salts. J. Am. Chem. Soc. 1963. 85(13): 1958.

22. Yoshida M., Morinaga Y., Iyoda M., Kikuchi K., Ikemoto I., Achiba Y. Reaction of $\mathrm{C}_{60}$ with diacyl peroxides containing perfluoroalkyl groups. The first example of electron transfer reaction via $\mathrm{C}_{60}{ }^{+}$.in solution. Tetrahedron Lett. 1993. 34(47): 7629.

23. Engel P.S., Billups W.E., Abmayr D.W., Tsvaygboym K., Wang R. Reaction of single-walled carbon nanotubes with organic peroxides. J. Phys. Chem. C. 2008. 112(3): 695.

24. Peng H., Reverdy P., Khabashesku V.N., Margrave J.L. Sidewall functionalization of single-walled carbon nanotubes with organic peroxides. Chem. Commun. 2003. 3: 362.

25. Brichka S.Y., Prikhod'ko G.P., Sementsov Y.I., Brichka A.V., Dovbeshko G.I., Paschuk O.P. Synthesis of carbon nanotubes from a chlorine-containing precursor and their properties. Carbon. 2004. 42(12-13): 2581.

26. Wang Z., Shirley M.D., Meikle S.T., Whitby R.L.D., Mikhalovsky S. The surface acidity of acid oxidized multi-walled carbon nanotubes and the influence of in-situ generated fulvic acids on their stability in aqueous dispersions. Carbon. 2009. 47(1): 73.

27. Boehm H.P. Surface oxides on carbon and their analysis: a critical assessment. Carbon. 2002. $40(2): 145$.

28. Briggs D., Search M.P. Practical Surface Analysis. (Chichester: Wiley, 1992).

29. Voitko K.V., Haliarnyk D.M., Bakalinska O.M., Kartel M.T. Factors determining the catalytic activity of multiwalled carbon nanotubes in the decomposition of diacyl peroxides in non-aqueous media. Catal Lett. 2017. 147(8): 1966.

30. Toth A., Voitko K.V., Bakalinska O., Prykhod'ko G.P., Bertoti I., Martinez-Alonso A., Tascon J.M.D., Gun'ko V.M., Laszlo K. Morphology and adsorption properties of chemically modified MWCNT probed by nitrogen, n-propane and water vapour. Carbon. 2012. 50(2): 577.

31. Chu H., Qiu S., Liu L., Zou Y., Xiang C., Zhang H., Xu F., Sun L., Zhou H., Wu G. Significantly enhanced dehydrogenation properties of calcium borohydride combined with urea. Dalton Trans. 2014. 43(41): 15291.

32. Figueiredo J.L., Pereira M.F.R., Freitas M.M.A., Órfão J.J.M. Modification of the surface chemistry of activated carbons. Carbon. 1999. 37(9): 1379.

33. Rocha R.P., Sousa J.P.S., Silva A.M.T., Pereira M.F.R., Figueiredo J.L. Catalytic activity and stability of multiwalled carbon nanotubes in catalytic wet air oxidation of oxalic acid: The role of the basic nature induced by the surface chemistry. Appl. Catal., B. 2011. 104(3-4): 330.

34. Pels R., Kapteijn F., Moulijn J.A., Zhu Q., Thomas K.M. Evolution of nitrogen functionalities in carbonaceous materials during pyrolysis. Carbon. 1995. 33(11): 1641.

35. Rodil S.E., Muhl S. Bonding in amorphous carbon nitride. Diamond Relat. Mater. 2004. 13(4-8): 1521.

36. Lin Y.C., Chiu P.W. Controllable graphene N-doping with ammonia plasma. Appl. Phys. Lett. 2010. 96(13): 133110. 
37. Gill G.B., Williams G.H. Aroyl peroxides. Part IV. The decomposition of benzoyl peroxide in nitrobenzene. The effect of added nitrobenzene on the decomposition of benzoyl peroxide in benzene. J. Chem. Soc. B. 1966. 0: 880 .

38. Pobedimskii D.G. Kinetics and mechanism of the reaction of peroxy-compounds with phosphites, sulphides, and aromatic amines. Russ. Chem. Rev. 1971. 40(2): 142.

39. Morsi S.E., Zaki A.B., El-Shamy T.M., Habib A. The role of charge transfer interactions in the decomposition of organic peroxides-I: Benzoyl peroxide-amine systems in non-restricted fluid media. Eur. Polym. J. 1976. 12: 417.

40. Morsi S.E., Zaki A.B., El-Khyami L.A. The role of charge transfer interactions in the decomposition of organic peroxides-II: Spontaneous and amine-induced decomposition of dibenzoyl peroxide in partially restricted media. Eur. Polym. J. 1977. 13(11): 851.

Received 21.06.2018, accepted 14.08.2018 